\title{
B7H3 As a Promoter of Metastasis and Promising Therapeutic Target
}

\author{
Peixin Dong ${ }^{1 *}$, Ying Xiong ${ }^{2 \dagger}$, Junming Yue ${ }^{3,4}$, Sharon J. B. Hanley ${ }^{1}$ and Hidemichi Watari ${ }^{1 *}$ \\ ${ }^{1}$ Department of Obstetrics and Gynecology, Hokkaido University School of Medicine, Hokkaido University, Sapporo, Japan, \\ ${ }^{2}$ Department of Gynecology, State Key Laboratory of Oncology in South China, Sun Yat-sen University Cancer Center, \\ Guangzhou, China, ${ }^{3}$ Department of Pathology and Laboratory Medicine, University of Tennessee Health Science Center, \\ Memphis, TN, United States, ${ }^{4}$ Center for Cancer Research, University of Tennessee Health Science Center, Memphis, TN, \\ United States
}

OPEN ACCESS

Edited by:

Jie Xu,

Shanghai Jiao Tong

University, China

Reviewed by:

Jin Qian,

Stanford University,

United States

Ye Hu,

Cedars-Sinai Medical Center,

United States

*Correspondence:

Peixin Dong

dpx1cn@gmail.com;

Hidemichi Watari

watarih@med.hokudai.ac.jp

tThese authors have contributed equally to this work.

Specialty section: This article was submitted to Pharmacology of Anti-Cancer Drugs, a section of the journal

Frontiers in Oncology

Received: 06 June 2018 Accepted: 26 June 2018

Published: 06 July 2018

Citation:

Dong P, Xiong Y, Yue J, Hanley SJB and Watari $H$ (2018) B7H3 As a

Promoter of Metastasis and

Promising Therapeutic Target.

Front. Oncol. 8:264.

doi: 10.3389/fonc.2018.00264
B7H3 (also known as CD276, an immune checkpoint molecule) is aberrantly overexpressed in many types of cancer, and such upregulation is generally associated with a poor clinical prognosis. Recent discoveries indicate a crucial role for $\mathrm{B} 7 \mathrm{H} 3$ in promoting carcinogenesis and metastasis. This review will focus on the latest developments relating specifically to the oncogenic activity of $\mathrm{B} 7 \mathrm{H} 3$ and will describe the upstream regulators and downstream effectors of $\mathrm{B} 7 \mathrm{H} 3$ in cancer. Finally, we discuss the emerging roles of microRNAs (miRNAs) in inhibiting B7H3-mediated tumor promotion. Excellent recent studies have shed new light on the functions of $\mathrm{B} 7 \mathrm{H} 3$ in cancer and identified $\mathrm{B} 7 \mathrm{H} 3$ as a critical promoter of tumor cell proliferation, migration, invasion, epithelial-tomesenchymal transition, cancer stemness, drug resistance, and the Warburg effect. Numerous miRNAs are reported to regulate the expression of B7H3. Our meta-analysis of miRNA database revealed that 17 common miRNAs potentially interact with $\mathrm{B} 7 \mathrm{H} 3$ mRNA. The analysis of the TCGA ovarian cancer dataset indicated that low miR-187 and miR-489 expression was associated with poor prognosis. Future studies aimed at delineating the precise cellular and molecular mechanisms underpinning B7H3-mediated tumor promotion will provide further insights into the cell biology of tumor development. In addition, inhibition of $\mathrm{B} 7 \mathrm{H} 3$ signaling, to be used alone or in combination with other treatments, will contribute to improvements in clinical practice and benefit cancer patients.

Keywords: B7H3, CD276, metastasis, epithelial-to-mesenchymal transition, cancer stem cells, microRNA

\section{INTRODUCTION}

Metastasis, or the consequences of their treatment, are the primary cause of cancer death (1). Metastasis is commonly viewed as a multistep event resulting in the dissemination of tumor cells from the primary tumor site to a distant location (2). These include loss of gap junction and tight junction contacts with neighboring cells, migration and invasion of basement membrane and extracellular matrix, entry and survival in the blood vascular and lymphatic system, extravasation into the parenchyma of distant tissues, adaptation to tumor microenvironment and host tissue remodeling, and re-initiation of their proliferative programs at metastatic sites $(3,4)$.

Epithelial-to-mesenchymal transition (EMT) endows epithelial tumor cells with enhanced motility and invasiveness $(5,6)$. Furthermore, EMT-derived tumor cells acquire cancer stem cell (CSC) properties and exhibit therapeutic resistance (6-9). In addition, the mutual interactions between tumor cells and the surrounding tumor microenvironment will eventually promote 
tumor development and metastasis (10). Tumor microenvironment comprises many cell types including immune cells, fibroblasts, and endothelial cells (11). Tumor cells frequently display altered expression of cytokines and chemokines that promote the infiltration and activity of suppressive immune cell populations and also express immune checkpoint molecules (such as programmed cell death 1 ligand 1 and $\mathrm{B} 7 \mathrm{H} 3$, also known as CD276) to inhibit the antitumor immune response $(12-17)$.

B7H3 is expressed on immune cells (such as antigenpresenting cells or macrophages) and tumor cells and has inhibitory roles on T cells, contributing to tumor cell immune evasion (18-20). Recent studies have shown that B7H3 is a crucial player in tumor growth and metastasis beyond the immune regulatory roles (21). The developments in our understanding of cancer biology have provided a better understanding of how $\mathrm{B} 7 \mathrm{H} 3$ regulates EMT and cancer stemness and of molecular mechanisms responsible for controlling the expression of $\mathrm{B} 7 \mathrm{H} 3$ in cancer.

Although there have been substantial advances in our understanding of cancer at the molecular level, its prevention and treatment are still lacking. Considering the significant roles of $\mathrm{B} 7 \mathrm{H} 3$ in cancer immunity and progression, the value of $\mathrm{B} 7 \mathrm{H} 3$ in cancer diagnosis and treatment warrants further detailed study. Here, we review our current knowledge of how dysregulation of B7H3 and its signaling pathways can influence the hallmarks of cancer and discuss the potential use of microRNA (miRNA) as a potential therapeutic strategy for $\mathrm{B} 7 \mathrm{H} 3$ overexpressing tumors, especially focusing on those miRNAs involved in the regulation of $\mathrm{B} 7 \mathrm{H} 3$ expression in ovarian cancer.

\section{B7H3 ACTIVATION IN CANCER}

B7H3 (CD276) belongs to the B7 superfamily of immune checkpoint molecules (22). It is present at low levels in most normal tissues but is overexpressed in a wide variety of cancers, including bladder, breast, cervical, colorectal, esophageal, glioma, kidney, liver, lung, ovarian, pancreatic, prostate, intrahepatic cholangiocarcinoma, liver, oral squamous cell carcinoma, endometrial cancer, and squamous cell carcinoma and gastric cancer (23-42), glioma (43), and melanoma (44) (Table 1). Numerous studies showed that the overexpression of B7H3 was correlated with advanced tumor stage and high tumor grade in endometrial, cervical, breast, kidney cancer, and oral squamous cell carcinoma $(25,28,30,39,40)$. The overexpression of B7H3 is associated with the proliferation and invasive potential of pancreatic, breast, colorectal, liver, prostate cancer, intrahepatic cholangiocarcinoma, and oral squamous cell carcinoma $(26,27$, $30-32,36-40)$. Notably, overexpression of B7H3 was found to correlate with poorer prognosis in many cancers $(25,28,29$, $31-34,36-40,44)$. However, high B7H3 expression predicts better survival for patients with gastric and pancreatic cancer $(41,45)$. A possible explanation for this discrepancy could be different cancer type (or subtypes), tumor heterogeneity, differences in sample size, and clinical stage, the time point of $\mathrm{B} 7 \mathrm{H} 3$ measurement and the different methodology used in research.

TABLE 1 | The association between B7H3 expression and clinicopathologic factors of human cancers.

\begin{tabular}{|c|c|c|c|c|c|c|c|c|c|}
\hline \multirow[t]{2}{*}{ Cancer type } & \multirow[t]{2}{*}{ No. } & \multirow[t]{2}{*}{ Method } & \multirow[t]{2}{*}{ Expression } & \multicolumn{5}{|c|}{ Clinical factors } & \multirow[t]{2}{*}{ Reference } \\
\hline & & & & Size & $\begin{array}{l}\text { Stage/ } \\
\text { grade }\end{array}$ & $\begin{array}{l}\text { Invasion } \\
\text { depth }\end{array}$ & $\begin{array}{l}\text { LN meta/ } \\
\text { recurrence }\end{array}$ & Survival & \\
\hline $\begin{array}{l}\text { Bladder, breast, cervical, colorectal, } \\
\text { esophageal, kidney, liver, lung, } \\
\text { ovarian, pancreatic, prostate } \\
\text { cancer, glioma, melanoma }\end{array}$ & 1,342 & $\mathrm{IHC}$ & Upregulation & NA & NA & NA & NA & NA & $(23)$ \\
\hline Bladder cancer & 302 & $\boxplus \mathrm{HC}$ & Upregulation & - & - & - & - & NA & $(24)$ \\
\hline Endometrial cancer & 107 & $\mathrm{IHC}$ & Upregulation & - & + & NA & NA & Poor & (25) \\
\hline Pancreatic cancer & 26 & ELISA & Upregulation & + & NA & NA & NA & NA & (26) \\
\hline Pancreatic cancer & 59 & $\mathrm{HC}$ & Upregulation & NA & + & NA & + & NA & $(27)$ \\
\hline Cervical cancer & 108 & $\mathrm{IHC}$ & Upregulation & + & - & - & - & Poor & $(28)$ \\
\hline Breast cancer & 90 & $\mathrm{IHC}$ & Upregulation & - & - & - & - & Poor & (29) \\
\hline Breast cancer & 82 & $\mathrm{HC} / \mathrm{qPCR}$ & Upregulation & + & + & - & + & NA & (30) \\
\hline Intrahepatic cholangiocarcinoma & 45 & $\mathrm{HC}$ & Upregulation & - & - & + & + & Poor & (31) \\
\hline Colorectal cancer & 275 & $\Vdash H C$ & Upregulation & NA & + & + & - & Poor & $(32)$ \\
\hline Ovarian cancer & 103 & $\mathrm{HC}$ & Upregulation & NA & + & - & - & Poor & (33) \\
\hline Glioma & 41 & $\|_{\mathrm{HC}}$ /microarray & Upregulation & NA & + & - & - & NA & $(43)$ \\
\hline Melanoma & 97 & $\mathrm{IHC} / \mathrm{qPCR}$ & Upregulation & NA & + & - & - & Poor & (44) \\
\hline Lung cancer & 270 & $\mathrm{IHC}$ & Upregulation & NA & + & NA & NA & Poor & (34) \\
\hline Lung cancer & 70 & $\mathrm{HC}$ & Upregulation & NA & - & NA & + & NA & (35) \\
\hline Liver cancer & 24 & $\mathrm{HC}$ & Upregulation & NA & + & + & - & Poor & $(36)$ \\
\hline Prostate cancer & 823 & $\mathrm{IHC}$ & Upregulation & NA & NA & + & + & Poor & $(37)$ \\
\hline Prostate cancer & 2,111 & Microarray & Upregulation & NA & + & NA & + & Poor & $(38)$ \\
\hline Oral squamous cell carcinoma & NA & $\mathrm{IHC}$ & Upregulation & + & + & - & - & Poor & (39) \\
\hline Kidney cancer & 743 & $\mathrm{IHC}$ & Upregulation & + & + & NA & NA & Poor & $(40)$ \\
\hline Pancreatic cancer & 96 & IHC/qPCR & Upregulation & NA & - & - & - & Better & $(41)$ \\
\hline Gastric cancer & 32 & $\mathrm{IHC} / \mathrm{qPCR}$ & Upregulation & - & - & - & - & Better & $(42)$ \\
\hline
\end{tabular}

LN meta, lymph node metastasis; NA, data were not available. 


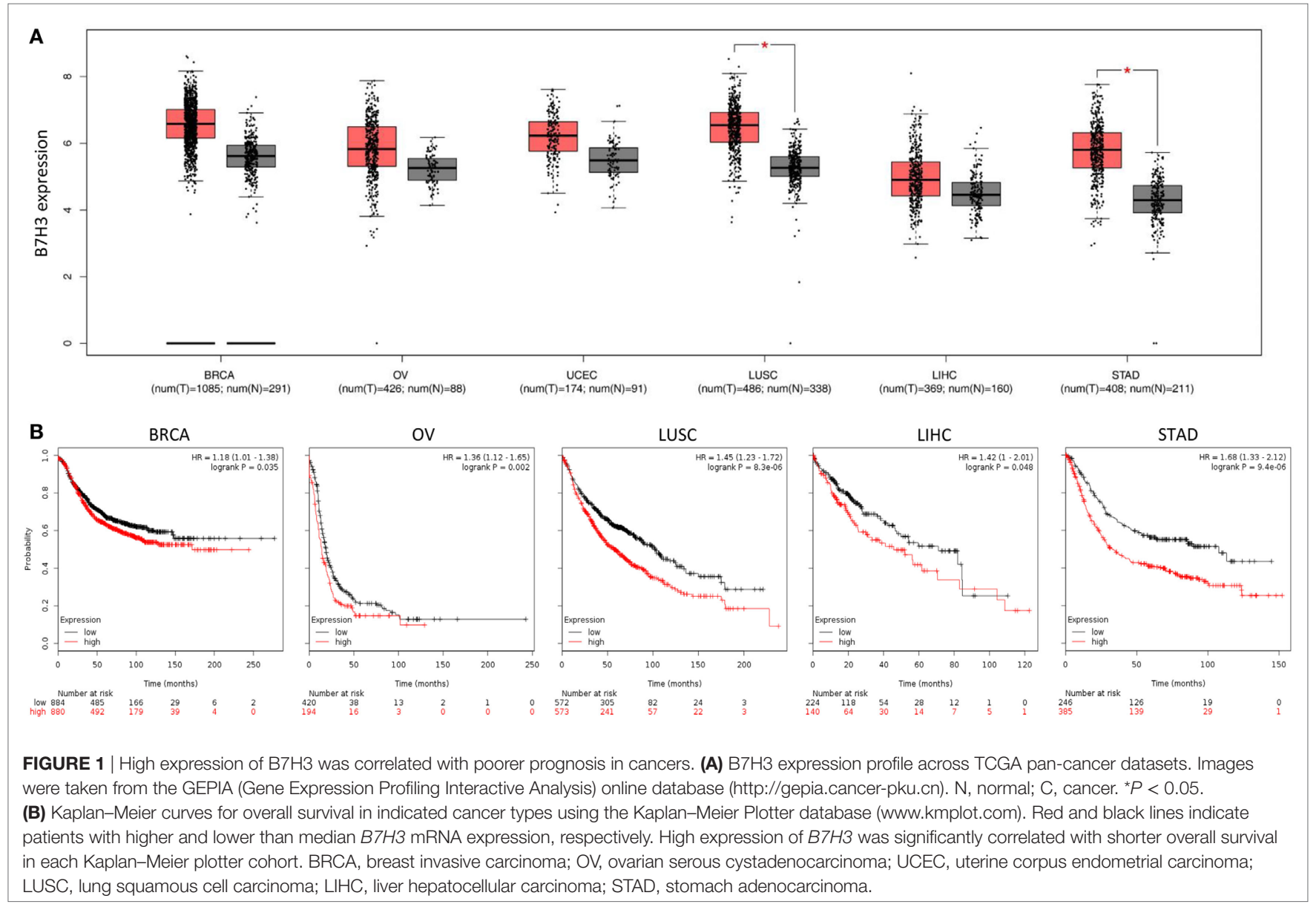

We assessed B7H3 expression in TCGA pan-cancer datasets obtained from Gene Expression Profiling Interactive Analysis (GEPIA) online database. ${ }^{1}$ In agreement with previous reports, RNA sequencing analysis of mRNA expression from the GEPIA online database (46) revealed that $\mathrm{B} 7 \mathrm{H} 3$ expression levels tend to be higher in breast, ovarian, endometrial, lung, liver, and gastric cancer tissues compared to corresponding normal tissues (Figure 1A). We also characterized the association between $\mathrm{B} 7 \mathrm{H} 3 \mathrm{mRNA}$ expression and prognosis in several cancers using the Kaplan-Meier plotter database ${ }^{2}$ (47). Higher expression of $\mathrm{B} 7 \mathrm{H} 3$ was significantly associated with shorter overall survival in breast, ovarian, lung, liver, and gastric cancer (Figure 1B).

\section{THE ROLES OF B7H3 IN DIFFERENT CANCER CELLS AND POSSIBLE MECHANISMS}

The following sections and Table 2 summarize the current understanding of the functional role of $\mathrm{B} 7 \mathrm{H} 3$ in metastasis and describe its underlying mechanisms in different tumor cells.

${ }^{1} \mathrm{http://gepia.cancer-pku} . c n$ (Accessed: June 5, 2018).

${ }^{2} \mathrm{http}: / / \mathrm{kmplot} . c o m /$ analysis/ (Accessed: June 5, 2018).

\section{ROLES OF B7H3 IN CANCER CELL PROLIFERATION AND INVASIVENESS}

Evidence supporting a tumor-promoting role for $\mathrm{B} 7 \mathrm{H} 3$ is now increasingly apparent from functional studies of diverse malignancies. A lot of evidence demonstrated that $\mathrm{B} 7 \mathrm{H} 3$ is involved in biological processes of cancer development, such as proliferation, migration, and invasion. For instance, knockdown of B7H3 expression in prostate, breast, gastric, liver, pancreatic, colorectal cancer cells, and melanoma cells could significantly suppress cell migration and invasion $(26,42,48-57)$.

Different molecular mechanisms may also underlie these effects: (1) B7H3 induced the migratory potential and invasiveness of tumor cells by increasing the expression of metastasisassociated proteins such as MMP2, STAT3 and IL-8 (50); (2) by increasing the levels of CXCR4 and activating AKT, ERK, and JAK2/STAT3 pathways (52); (3) through activating the JAK2/ STAT3/MMP9 pathway (55); (4) by increasing the expression of MMP2 (56); (5) by activating the TLR4/NF-KB signaling and increased IL-8 and VEGF expression (57).

Several studies have provided convincing in vivo functional data that are consistent with the data from cancer cell lines and thus support the tumor-promoting role of $\mathrm{B} 7 \mathrm{H} 3$ during cancer progression. For example, in the subcutaneous transplantation pancreatic cancer mouse model, tumor growth rate was reduced 
TABLE 2 | Roles, functions, and mechanisms of B7H3 in cancer

\begin{tabular}{|c|c|c|c|c|}
\hline Cancer type & Role & Function & Mechanism & Reference \\
\hline Prostate cancer & Oncogene & Migration, invasion & NA & $(48)$ \\
\hline Melanoma/breast cancer & Oncogene & Migration, invasion & NA & $(49)$ \\
\hline Melanoma/breast cancer & Oncogene & Migration, invasion & Increased the expression of MMP2, STAT3, and IL-8 & $(50)$ \\
\hline Melanoma & Oncogene & $\begin{array}{l}\text { Proliferation, glycolytic capacity, resistance to } \\
\text { chemotherapy and small-molecule inhibitors }\end{array}$ & NA & $(51)$ \\
\hline Breast cancer & Oncogene & Paclitaxel resistance & Activated JAK2/STAT3 pathway & (64) \\
\hline Breast cancer & Oncogene & $\begin{array}{l}\text { Glucose uptake, lactate production, } \\
\text { proliferation }\end{array}$ & $\begin{array}{l}\text { Increased the expression of HIF1 } \alpha \text { and its downstream } \\
\text { targets, LDHA and PDK1 }\end{array}$ & $(70)$ \\
\hline Gastric cancer & Oncogene & Migration, invasion, proliferation & NA & $(42)$ \\
\hline Gastric cancer & Oncogene & Migration, invasion & $\begin{array}{l}\text { Increased CXCR4; and activated AKT, ERK, and JAK2/ } \\
\text { STAT3 phosphorylation }\end{array}$ & $(52)$ \\
\hline $\begin{array}{l}\text { Esophageal squamous cell } \\
\text { carcinoma }\end{array}$ & Oncogene & Migration, invasion & $\mathrm{NA}$ & $(53)$ \\
\hline Liver cancer & Oncogene & Proliferation, adhesion, migration, and invasion & NA & $(54)$ \\
\hline Pancreatic cancer & Oncogene & Proliferation, invasion & NA & (26) \\
\hline Colorectal cancer & Oncogene & Resistance to chemotherapy & Activated JAK2/STAT3 pathway & $(65)$ \\
\hline Colorectal cancer & Oncogene & Oxaliplatin resistance & Increased the expression of XRCC1 via PI3K/AKT pathway & $(66)$ \\
\hline Colorectal cancer & Oncogene & Migration, invasion & Activated JAK2/STAT3/MMP9 pathway & $(55)$ \\
\hline Colorectal cancer & Oncogene & Resistance to chemotherapy & Increased BRCC3 expression & $(67)$ \\
\hline Colorectal cancer & Oncogene & Resistance to chemotherapy & Activated PI3K/AKT/TS pathway & $(68)$ \\
\hline Colorectal cancer & Oncogene & $\begin{array}{l}\text { Epithelial-to-mesenchymal transition, } \\
\text { cancer stemness }\end{array}$ & $\begin{array}{l}\text { Decreased E-cadherin expression and increased of } \\
\text { N-cadherin, Vimentin, CD133, CD44, and OCT4 expression }\end{array}$ & $(59)$ \\
\hline Osteosarcoma & Oncogene & Invasion & Increased the expression of MMP2 & $(56)$ \\
\hline Pancreatic cancer & Oncogene & Invasion, metastasis & $\begin{array}{l}\text { Activated TLR4/NF-кB signaling and increased IL-8 and } \\
\text { VEGF expression }\end{array}$ & $(57)$ \\
\hline Glioma & Oncogene & Migration, invasion, cancer stemness & NA & $(61)$ \\
\hline Ovarian cancer & Oncogene & $\begin{array}{l}\text { Resistance to chemotherapy and small- } \\
\text { molecule inhibitors, cancer stemness }\end{array}$ & Possibly increased the expression of ALDH & $(60)$ \\
\hline
\end{tabular}

NA, data were not available.

by the knockdown of B7H3 (26). Similarly, the silencing of B7H3 significantly decreased tumor proliferation in mantle cell lymphoma in vitro and in vivo (58).

\section{B7H3 MEDIATES EMT AND CSC IN CANCER CELLS}

Some researchers claimed that $\mathrm{B} 7 \mathrm{H} 3$ plays a key role in modulating EMT and CSC-like properties of various cancer cells. B7H3 can promote EMT and cancer stemness by decreasing E-cadherin expression and increasing the expression of $\mathrm{N}$-cadherin, Vimentin, CD133, CD44, and OCT4 (59). Blockade of B7H3 with a monoclonal antibody reduced the number of cancer-initiating cells (60). A previous study found that B7H3 is an inducer of cell invasion and sphere formation in glioma cells (61), further suggesting a role of $\mathrm{B} 7 \mathrm{H} 3$ in the cancer invasion process.

Cancer stem cells or tumor-initiating cells not only possess the ability of self-renewal but also develop strong resistance to chemotherapy (62). It was demonstrated that the induction of EMT generated cells with properties of CSCs (63). In breast cancer and colorectal cancer cells, $\mathrm{B} 7 \mathrm{H} 3$ induced the resistance to paclitaxel or 5-fluorouracil (5-FU) through activating the JAK2/ STAT3 pathway $(64,65)$. In addition, a few other mechanisms may also underlie B7H3-mediated chemoresistance: (1) B7H3 induces oxaliplatin resistance by increasing the expression of XRCC1 via PI3K/AKT pathway (66); (2) B7H3 also enhances cell resistance to chemotherapy by increasing the expression of BRCC3, which antagonizes DNA damage caused by 5-FU (67); (3) or via the activation of the PI3K/AKT pathway (68).

\section{ROLE OF B7H3 IN CANCER METABOLISM}

Warburg effect (or aerobic glycolysis) is a metabolic hallmark of cancer, characterized by an excessive conversion of glucose to lactate even with ample oxygen (69). A recent study found that B7H3 can promote the Warburg effect, evidenced by increased glucose uptake and lactate production in breast cancer cells. Furthermore, this stimulating effect of $\mathrm{B} 7 \mathrm{H} 3$ on the Warburg effect was also observed in a mouse model of breast cancer (70). Mechanistically, B7H3-induced metabolic shift in cancer cells is mediated by HIF1 $\alpha$, a master regulator in the reprogramming of cancer metabolism in favor of glycolysis (70), revealing a new mechanism for the Warburg effect in cancer cells. Reasonably, we believe treating tumors by targeting their metabolism through modulation of $\mathrm{B} 7 \mathrm{H} 3$ expression would probably generate a better effect of tumor eradication.

\section{REGULATORY MECHANISMS OF B7H3 IN CANCER}

Protein expression is usually controlled by the following mechanisms: the genetic aberrations of the gene loci (71), 
transcriptional regulation (72), posttranscriptional regulation at the mRNA level (73), and protein modification (74). Epigenetic mechanisms such as DNA methylation (75), histone modification (76), and non-coding RNAs $(77,78)$ play a key role in regulating gene expression. DNA methylation and modification of histones mediate gene transcription, and miRNAs regulate gene expression posttranscriptionally (79). To date, it is less clear whether $\mathrm{B} 7 \mathrm{H} 3$ overexpression observed in cancer is due to genomic DNA amplification, or which transcription factors are responsible for B7H3 transcription. However, chromatin immunoprecipitation analysis in prostate cancer cells revealed an androgen receptorbinding site upstream of $\mathrm{B} 7 \mathrm{H} 3$, and the presence of androgens decreased B7H3 expression (38).

Interestingly, immunoglobulin-like transcript-4 (ILT4) is an inhibitory receptor that inhibits the function of certain immune cells and was shown to upregulate $\mathrm{B} 7 \mathrm{H} 3$ expression via the PI3K/ AKT/mTOR signaling in lung cancer cells (80). Co-expression of ILT4 and B7H3 was positively corelated with lymph node metastasis and advanced tumor stage (80). Consequently, further study is needed to elaborate the link between ILT4 and B7H3 in different cancer cells.

At the posttranscriptional level, numerous miRNAs, including miR-214, miR-363*, miR-326, miR-940, miR-29c, miR-665, miR34b*, miR-708, miR-601, miR-124a, miR-380-5p, miR-885-3p, and miR-593, directly interact with the $3^{\prime}$-UTR of B7H3 mRNA, resulting in attenuation of $\mathrm{B} 7 \mathrm{H} 3$ expression in breast cancer (81). miR-124 also binds directly to the $3^{\prime}$-UTR of B7H3 mRNA, inhibiting its expression in osteosarcoma (82). TGF- $\beta 1$ through SMAD3 and SMAD4 elevated miR-155 expression, which in turn attenuated CEBPB expression and consequently miR-143 expression in colorectal cancer cells. As a result, the reduction of miR143 led to the upregulation of B7H3, a direct target of miR-143 (83). These results indicated that TGF- $\beta 1$ may promote cancer immune escape by upregulating $\mathrm{B} 7 \mathrm{H} 3$ expression. In addition, a recent study demonstrated that p53 binds to the promoter of miR-124 to elevate its expression in colorectal cancer cells (84). Meanwhile, iASPP, a novel oncoprotein overexpressed in many cancers, interacts with p53 to suppress p53-mediated transcription of target genes $(75,85)$. Thus, these results indicate a possible mechanism underlying $\mathrm{B} 7 \mathrm{H} 3$ overexpression in tumors: iASPPmediated p53 repression leads to the downregulation of miR-124, subsequently resulting in increased expression of $\mathrm{B} 7 \mathrm{H} 3$.

We used three computational algorithms, including TargetScan, ${ }^{3}$ miRSystem, ${ }^{4}$ and DIANA-MicroT-CDS ${ }^{5}$ to identify miRNAs that might regulate $\mathrm{B} 7 \mathrm{H} 3$ expression. This analysis revealed 17 common miRNAs predicted to bind the $3^{\prime}$-UTR of the B7H3 transcript (Figures 2A,B). In colorectal cancer cells, a recent study showed that miR-187 binds B7H3 mRNA and suppresses its expression to inhibit cell proliferation, migration, invasion, and induced cell apoptosis (86). In clear cell renal cell carcinoma, another study confirmed that $\mathrm{B} 7 \mathrm{H} 3$ expression is downregulated by miR-187, a tumor suppressor that suppresses

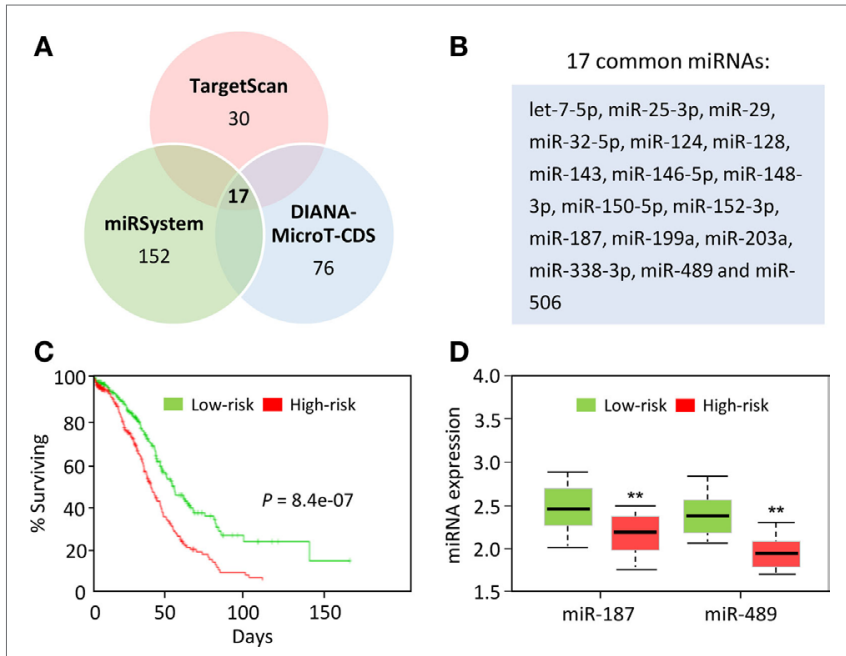

FIGURE 2 | MicroRNAs (miRNAs) that potentially regulate B7H3 expression in ovarian cancer. (A) Venn diagram showing the overlap of miRNAs that were predicted to bind to the B7H3 $3^{\prime}$-UTR by alternative algorithms (TargetScan, miRSystem, and DIANA-MicroT-CDS). (B) The 17 predicted miRNAs were common to these three algorithms. (C) The Kaplan-Meier survival curves of 458 TCGA (Cancer Genome Atlas database) ovarian cancer samples were created using the SurvMicro database based on the low $(n=229)$ or high $(n=229)$ risk for a poor outcome. (D) Box plots demonstrating significantly lower levels of miR-187 and miR-489 expression in the high-risk ovarian cancer patients.

cancer cell proliferation and motility (87). Collectively, these data suggest that the loss of tumor suppressor miRNAs activate $\mathrm{B} 7 \mathrm{H} 3$ and contributes to cancer progression.

We further evaluated the correlation of patient survival with the expression of these miRNAs in ovarian cancer samples in the TCGA by using the online software SurvMicro. ${ }^{6}$ Ovarian patients were stratified into the high-risk (with a low probability of survival; $n=229$ ) or low-risk (with a high probability of survival; $n=229$ ) group $(P=8.4 \mathrm{E}-07$, Figure $2 \mathrm{C})$. High-risk patients had lower miR-187 and miR-489 expression levels than the low-risk patients (Figure 2D). Thus, these 17 miRNAs, especially miR-187 and miR-489, are expected to have binding sites in the 3 '-UTR of $\mathrm{B} 7 \mathrm{H} 3$ in cancer cells, although functional validation remains to be performed.

\section{CONCLUSION}

Interruption of metastasis pathways holds preclinical and clinical promise as an anti-metastasis therapy. The emerging role of $\mathrm{B} 7 \mathrm{H} 3$ in human tumor cells and in inducing EMT/CSC-like features have been noted. Furthermore, tumor cells could rely on Warburg effect to generate energy (88). The recent findings led to the identification of B7HH3 as a contributor to the Warburg effect (70). Therefore, targeting the metastatic potential and metabolic changes with inhibitors against $\mathrm{B} 7 \mathrm{H} 3$ may be a promising way for cancer therapy.

${ }^{6}$ http://bioinformatica.mty.itesm.mx:8080/Biomatec/Survmicro.jsp June 5, 2018).

${ }^{3}$ http://www.targetscan.org/vert_72/ (Accessed: June 5, 2018).

${ }^{4} \mathrm{http} / / /$ mirsystem.cgm.ntu.edu.tw/ (Accessed: June 5, 2018).

${ }^{5} \mathrm{http} / / /$ diana.imis.athena-innovation.gr/DianaTools/index.php? $\mathrm{r}=$ microT_CDS/ index (Accessed: June 5, 2018). 
The induced B7H3 expression has been detected in multiple cancers as compared with normal tissues. The $\mathrm{B} 7 \mathrm{H} 3$ protein, especially when located in the cell membrane, may be a perfect choice for targeted drug development. Importantly, the treatment with an inhibitory $\mathrm{B} 7 \mathrm{H} 3$ monoclonal antibody in melanoma cells leads to decreased proliferation and Warburg effect (51). Additionally, targeting $\mathrm{B} 7 \mathrm{H} 3$ with a monoclonal antibody has demonstrated the safety and efficacy in the salvage treatment of stage IV childhood neuroblastoma (43). Activated T cell (ATC) armed with a novel anti-CD3 $\times$ anti-B7H3 bispecific antibody was found to significantly inhibit lung cancer growth in vivo compared with unarmed ATC (89), indicating that targeting $\mathrm{B} 7 \mathrm{H} 3$ represent a novel alternative to improve current cancer therapy.

Future studies aimed at delineating the precise cellular and molecular mechanisms underpinning B7H3-mediated tumor promotion will provide further insights into the cell biology of

\section{REFERENCES}

1. Steeg PS. Targeting metastasis. Nat Rev Cancer (2016) 16(4):201-18. doi:10.1038/nrc.2016.25

2. Valastyan S, Weinberg RA. Tumor metastasis: molecular insights and evolving paradigms. Cell (2011) 147(2):275-92. doi:10.1016/j.cell.2011.09.024

3. Pein M, Oskarsson T. Microenvironment in metastasis: roadblocks and supportive niches. Am J Physiol Cell Physiol (2015) 309(10):C627-38. doi:10.1152/ ajpcell.00145.2015

4. Descot A, Oskarsson T. The molecular composition of the metastatic niche. Exp Cell Res (2013) 319(11):1679-86. doi:10.1016/j.yexcr.2013.04.017

5. Nieto MA, Huang RY, Jackson RA, Thiery JP. EMT: 2016. Cell (2016) 166(1):21-45. doi:10.1016/j.cell.2016.06.028

6. Zhou P, Li B, Liu F, Zhang M, Wang Q, Liu Y, et al. The epithelial to mesenchymal transition (EMT) and cancer stem cells: implication for treatment resistance in pancreatic cancer. Mol Cancer (2017) 16(1):52. doi:10.1186/ s12943-017-0624-9

7. Shibue T, Weinberg RA. EMT, CSCs, and drug resistance: the mechanistic link and clinical implications. Nat Rev Clin Oncol (2017) 14(10):611-29. doi:10.1038/nrclinonc.2017.44

8. Ma J, Zeng S, Zhang Y, Deng G, Qu Y, Guo C, et al. BMP4 promotes oxaliplatin resistance by an induction of epithelial-mesenchymal transition via MEK1/ERK/ELK1 signaling in hepatocellular carcinoma. Cancer Lett (2017) 411:117-29. doi:10.1016/j.canlet.2017.09.041

9. Thomson S, Buck E, Petti F, Griffin G, Brown E, Ramnarine N, et al. Epithelial to mesenchymal transition is a determinant of sensitivity of non-small-cell lung carcinoma cell lines and xenografts to epidermal growth factor receptor inhibition. Cancer Res (2005) 65(20):9455-62. doi:10.1158/0008-5472.CAN05-1058

10. Ungefroren H, Sebens S, Seidl D, Lehnert H, Hass R. Interaction of tumor cells with the microenvironment. Cell Commun Signal (2011) 9:18. doi:10.1186/ 1478-811X-9-18

11. Quail DF, Joyce JA. Microenvironmental regulation of tumor progression and metastasis. Nat Med (2013) 19(11):1423-37. doi:10.1038/nm.3394

12. Gajewski TF, Meng Y, Harlin H. Immune suppression in the tumor microenvironment. J Immunother (2006) 29(3):233-40. doi:10.1097/01. cji.0000199193.29048.56

13. Wu AA, Drake V, Huang HS, Chiu S, Zheng L. Reprogramming the tumor microenvironment: tumor-induced immunosuppressive factors paralyze T cells. Oncoimmunology (2015) 4(7):e1016700. doi:10.1080/2162402X.2015. 1016700

14. Jenkins RW, Barbie DA, Flaherty KT. Mechanisms of resistance to immune checkpoint inhibitors. Br J Cancer (2018) 118(1):9-16. doi:10.1038/bjc. 2017.434

15. Bidnur S, Savdie R, Black PC. Inhibiting immune checkpoints for the treatment of bladder cancer. Bladder Cancer (2016) 2(1):15-25. doi:10.3233/ BLC-150026 tumor development. In addition, inhibition of $\mathrm{B} 7 \mathrm{H} 3$ signaling, to be used alone or in combination with other treatments, will contribute to improvements in clinical practice and benefit cancer patients.

\section{AUTHOR CONTRIBUTIONS}

PD and HW provided direction. PD, YX, and HW wrote the manuscript. JY and SH made significant revisions to the manuscript. All authors read and approved the final manuscript.

\section{FUNDING}

This work was supported by a grant from JSPS Grant-in-Aid for Scientific Research (C) (16K11123 and 18K09278) and the Science and Technology Planning Project of Guangdong Province, China (2014A020212124).

16. Voutsadakis IA. Immune blockade inhibition in breast cancer. Anticancer Res (2016) 36(11):5607-22. doi:10.21873/anticanres.11145

17. Marcucci F, Rumio C, Corti A. Tumor cell-associated immune checkpoint molecules - Drivers of malignancy and stemness. Biochim Biophys Acta (2017) 1868(2):571-83. doi:10.1016/j.bbcan.2017.10.006

18. Castellanos JR, Purvis IJ, Labak CM, Guda MR, Tsung AJ, Velpula KK, et al. B7-H3 role in the immune landscape of cancer. Am J Clin Exp Immunol (2017) 6(4):66-75.

19. Chen C, Shen Y, Qu QX, Chen XQ, Zhang XG, Huang JA. Induced expression of B7-H3 on the lung cancer cells and macrophages suppresses T-cell mediating anti-tumor immune response. Exp Cell Res (2013) 319(1):96-102. doi:10.1016/j.yexcr.2012.09.006

20. Vigdorovich V, Ramagopal UA, Lázár-Molnár E, Sylvestre E, Lee JS, Hofmeyer KA, et al. Structure and T cell inhibition properties of B7 family member, B7-H3. Structure (2013) 21(5):707-17. doi:10.1016/j.str.2013.03.003

21. Nygren MK, Tekle C, Ingebrigtsen VA, Fodstad O. B7-H3 and its relevance in cancer; immunological and non-immunological perspectives. Front Biosci (Elite Ed) (2011) 3:989-93. doi:10.2741/e304

22. Chapoval AI, Ni J, Lau JS, Wilcox RA, Flies DB, Liu D, et al. B7-H3: a costimulatory molecule for $\mathrm{T}$ cell activation and IFN-gamma production. Nat Immunol (2001) 2(3):269-74. doi:10.1038/85339

23. Seaman S, Zhu Z, Saha S, Zhang XM, Yang MY, Hilton MB, et al. Eradication of tumors through simultaneous ablation of CD276/B7-H3-positive tumor cells and tumor vasculature. Cancer Cell (2017) 31(4):501.e-15.e. doi:10.1016/j. ccell.2017.03.005

24. Xylinas E, Robinson BD, Kluth LA, Volkmer BG, Hautmann R, Küfer R, et al. Association of T-cell co-regulatory protein expression with clinical outcomes following radical cystectomy for urothelial carcinoma of the bladder. Eur J Surg Oncol (2014) 40(1):121-7. doi:10.1016/j.ejso.2013.08.023

25. Brunner A, Hinterholzer S, Riss P, Heinze G, Brustmann H. Immunoexpression of B7-H3 in endometrial cancer: relation to tumor T-cell infiltration and prog nosis. Gynecol Oncol (2012) 124(1):105-11. doi:10.1016/j.ygyno.2011.09.012

26. Zhao X, Li DC, Zhu XG, Gan WJ, Li Z, Xiong F, et al. B7-H3 overexpression in pancreatic cancer promotes tumor progression. Int J Mol Med (2013) 31(2):283-91. doi:10.3892/ijmm.2012.1212

27. Yamato I, Sho M, Nomi T, Akahori T, Shimada K, Hotta K, et al. Clinical importance of B7-H3 expression in human pancreatic cancer. Br J Cancer (2009) 101(10):1709-16. doi:10.1038/sj.bjc.6605375

28. Huang C, Zhou L, Chang X, Pang X, Zhang H, Zhang S. B7-H3, B7-H4, Foxp3 and IL-2 expression in cervical cancer: associations with patient outcome and clinical significance. Oncol Rep (2016) 35(4):2183-90. doi:10.3892/or. 2016.4607

29. Maeda N, Yoshimura K, Yamamoto S, Kuramasu A, Inoue M, Suzuki N, et al. Expression of B7-H3, a potential factor of tumor immune evasion in combination with the number of regulatory $\mathrm{T}$ cells, affects against recurrence-free survival in breast cancer patients. Ann Surg Oncol (2014) 21(Suppl 4):S546-54 doi:10.1245/s10434-014-3564-2 
30. Arigami T, Narita N, Mizuno R, Nguyen L, Ye X, Chung A, et al. B7-H3 ligand expression by primary breast cancer and associated with regional nodal metastasis. Ann Surg (2010) 252(6):1044-51. doi:10.1097/SLA.0b013e3181f1939d

31. Cheng R, Chen Y, Zhou H, Wang B, Du Q, Chen Y. B7-H3 expression and its correlation with clinicopathologic features, angiogenesis, and prognosis in intrahepatic cholangiocarcinoma. APMIS (2018) 126(5):396-402. doi:10.1111/apm.12837

32. Ingebrigtsen VA, Boye K, Tekle C, Nesland JM, Flatmark K, Fodstad O. B7-H3 expression in colorectal cancer: nuclear localization strongly predicts poor outcome in colon cancer. Int J Cancer (2012) 131(11):2528-36. doi:10.1002/ ijc. 27566

33. Zang X, Sullivan PS, Soslow RA, Waitz R, Reuter VE, Wilton A, et al. Tumor associated endothelial expression of B7-H3 predicts survival in ovarian carcinomas. Mod Pathol (2010) 23(8):1104-12. doi:10.1038/modpathol.2010.95

34. Inamura K, Yokouchi Y, Kobayashi M, Sakakibara R, Ninomiya H, Subat S, et al. Tumor B7-H3 (CD276) expression and smoking history in relation to lung adenocarcinoma prognosis. Lung Cancer (2017) 103:44-51. doi:10.1016/j. lungcan.2016.11.013

35. Sun Y, Wang Y, Zhao J, Gu M, Giscombe R, Lefvert AK, et al. B7-H3 and B7-H4 expression in non-small-cell lung cancer. Lung Cancer (2006) 53(2):143-51. doi:10.1016/j.lungcan.2006.05.012

36. Sun TW, Gao Q, Qiu SJ, Zhou J, Wang XY, Yi Y, et al. B7-H3 is expressed in human hepatocellular carcinoma and is associated with tumor aggressiveness and postoperative recurrence. Cancer Immunol Immunother (2012) 61(11):2171-82. doi:10.1007/s00262-012-1278-5

37. Zang X, Thompson RH, Al-Ahmadie HA, Serio AM, Reuter VE, Eastham JA, et al. B7-H3 and B7x are highly expressed in human prostate cancer and associated with disease spread and poor outcome. Proc Natl Acad Sci U S A (2007) 104(49):19458-63. doi:10.1073/pnas.0709802104

38. Benzon B, Zhao SG, Haffner MC, Takhar M, Erho N, Yousefi K, et al. Correlation of B7-H3 with androgen receptor, immune pathways and poor outcome in prostate cancer: an expression-based analysis. Prostate Cancer Prostatic Dis (2017) 20(1):28-35. doi:10.1038/pcan.2016.49

39. Chen JT, Chen CH, Ku KL, Hsiao M, Chiang CP, Hsu TL, et al. Glycoprotein B7-H3 overexpression and aberrant glycosylation in oral cancer and immune response. Proc Natl Acad Sci U S A (2015) 112(42):13057-62. doi:10.1073/ pnas.1516991112

40. Crispen PL, Sheinin Y, Roth TJ, Lohse CM, Kuntz SM, Frigola X, et al. Tumor cell and tumor vasculature expression of $\mathrm{B} 7-\mathrm{H} 3$ predict survival in clear cell renal cell carcinoma. Clin Cancer Res (2008) 14(16):5150-7. doi:10.1158/10780432.CCR-08-0536

41. Loos M, Hedderich DM, Ottenhausen M, Giese NA, Laschinger M, Esposito I, et al. Expression of the costimulatory molecule B7-H3 is associated with prolonged survival in human pancreatic cancer. BMC Cancer (2009) 9:463. doi:10.1186/1471-2407-9-463

42. Dai W, Shen G, Qiu J, Zhao X, Gao Q. Aberrant expression of B7-H3 in gastric adenocarcinoma promotes cancer cell metastasis. Oncol Rep (2014) 32(5):2086-92. doi:10.3892/or.2014.3405

43. Zhou Z, Luther N, Ibrahim GM, Hawkins C, Vibhakar R, Handler MH, et al. $\mathrm{B} 7-\mathrm{H} 3$, a potential therapeutic target, is expressed in diffuse intrinsic pontine glioma. J Neurooncol (2013) 111(3):257-64. doi:10.1007/s11060-012-1021-2

44. Wang J, Chong KK, Nakamura Y, Nguyen L, Huang SK, Kuo C, et al. B7$\mathrm{H} 3$ associated with tumor progression and epigenetic regulatory activity in cutaneous melanoma. J Invest Dermatol (2013) 133(8):2050-8. doi:10.1038/ jid.2013.114

45. Wu CP, Jiang JT, Tan M, Zhu YB, Ji M, Xu KF, et al. Relationship between co-stimulatory molecule B7-H3 expression and gastric carcinoma histology and prognosis. World J Gastroenterol (2006) 12(3):457-9. doi:10.3748/wjg. v12.i3.457

46. Tang Z, Li C, Kang B, Gao G, Li C, Zhang Z. GEPIA: a web server for cancer and normal gene expression profiling and interactive analyses. Nucleic Acids Res (2017) 45(W1):W98-102. doi:10.1093/nar/gkx247

47. Györffy B, Lanczky A, Eklund AC, Denkert C, Budczies J, Li Q, et al. An online survival analysis tool to rapidly assess the effect of 22,277 genes on breast cancer prognosis using microarray data of 1,809 patients. Breast Cancer Res Treat (2010) 123(3):725-31. doi:10.1007/s10549-009-0674-9

48. Yuan H, Wei X, Zhang G, Li C, Zhang X, Hou J. B7-H3 over expression in prostate cancer promotes tumor cell progression. J Urol (2011) 186(3):1093-9. doi:10.1016/j.juro.2011.04.103
49. Chen YW, Tekle C, Fodstad O. The immunoregulatory protein human B7H3 is a tumor-associated antigen that regulates tumor cell migration and invasion. Curr Cancer Drug Targets (2008) 8(5):404-13. doi:10.2174/156800908785133141

50. Tekle C, Nygren MK, Chen YW, Dybsjord I, Nesland JM, Maelandsmo GM, et al. B7-H3 contributes to the metastatic capacity of melanoma cells by modulation of known metastasis-associated genes. Int J Cancer (2012) 130(10):2282-90. doi:10.1002/ijc.26238

51. Flem-Karlsen K, Tekle C, Andersson Y, Flatmark K, Fodstad Ø, Nunes-Xavier CE. Immunoregulatory protein $\mathrm{B} 7-\mathrm{H} 3$ promotes growth and decreases sensitivity to therapy in metastatic melanoma cells. Pigment Cell Melanoma Res (2017) 30(5):467-76. doi:10.1111/pcmr.12599

52. Li Y, Yang X, Wu Y, Zhao K, Ye Z, Zhu J, et al. B7-H3 promotes gastric cancer cell migration and invasion. Oncotarget (2017) 8(42):71725-35. doi:10.18632/ oncotarget. 17847

53. Wang L, Cao NN, Wang S, Man HW, Li PF, Shan BE. Roles of coinhibitory molecules B7-H3 and B7-H4 in esophageal squamous cell carcinoma. Tumour Biol (2016) 37(3):2961-71. doi:10.1007/s13277-015-4132-5

54. Wang F, Wang G, Liu T, Yu G, Zhang G, Luan X. B7-H3 was highly expressed in human primary hepatocellular carcinoma and promoted tumor progression. Cancer Invest (2014) 32(6):262-71. doi:10.3109/07357907.2014.909826

55. Liu F, Zhang T, Zou S, Jiang B, Hua D. B7-H3 promotes cell migration and invasion through the Jak2/Stat3/MMP9 signaling pathway in colorectal cancer. Mol Med Rep (2015) 12(4):5455-60. doi:10.3892/mmr.2015.4050

56. Wang L, Zhang Q, Chen W, Shan B, Ding Y, Zhang G, et al. B7-H3 is overexpressed in patients suffering osteosarcoma and associated with tumor aggressiveness and metastasis. PLoS One (2013) 8(8):e70689. doi:10.1371/journal. pone. 0070689

57. Xie C, Liu D, Chen Q, Yang C, Wang B, Wu H. Soluble B7-H3 promotes the invasion and metastasis of pancreatic carcinoma cells through the TLR4/ NF-кB pathway. Sci Rep (2016) 6:27528. doi:10.1038/srep27528

58. Zhang W, Wang Y, Wang J, Dong F, Zhu M, Wan W, et al. B7-H3 silencing inhibits tumor progression of mantle cell lymphoma and enhances chemosensitivity. Int J Oncol (2015) 46(6):2562-72. doi:10.3892/ijo.2015.2962

59. Jiang B, Zhang T, Liu F, Sun Z, Shi H, Hua D, et al. The co-stimulatory molecule B7-H3 promotes the epithelial-mesenchymal transition in colorectal cancer. Oncotarget (2016) 7(22):31755-71. doi:10.18632/oncotarget.9035

60. Fauci JM, Sabbatino F, Wang Y, Londoño-Joshi AI, Straughn JM Jr., Landen CN, et al. Monoclonal antibody-based immunotherapy of ovarian cancer: targeting ovarian cancer cells with the B7-H3-specific mAb 376.96. Gynecol Oncol (2014) 132(1):203-10. doi:10.1016/j.ygyno.2013.10.038

61. Lemke D, Pfenning PN, Sahm F, Klein AC, Kempf T, Warnken U, et al. Costimulatory protein $4 \mathrm{IgB} 7 \mathrm{H} 3$ drives the malignant phenotype of glioblastoma by mediating immune escape and invasiveness. Clin Cancer Res (2012) 18(1):105-17. doi:10.1158/1078-0432.CCR-11-0880

62. Dean M, Fojo T, Bates S. Tumour stem cells and drug resistance. Nat Rev Cancer (2005) 5(4):275-84. doi:10.1038/nrc1590

63. Morel AP, Lièvre M, Thomas C, Hinkal G, Ansieau S, Puisieux A. Generation of breast cancer stem cells through epithelial-mesenchymal transition. PLoS One (2008) 3(8):e2888. doi:10.1371/journal.pone.0002888

64. Liu H, Tekle C, Chen YW, Kristian A, Zhao Y, Zhou M, et al. B7-H3 silencing increases paclitaxel sensitivity by abrogating Jak2/Stat3 phosphorylation. Mol Cancer Ther (2011) 10(6):960-71. doi:10.1158/1535-7163.MCT-11-0072

65. Zhang T, Jiang B, Zou ST, Liu F, Hua D. Overexpression of B7-H3 augments anti-apoptosis of colorectal cancer cells by Jak2-STAT3. World J Gastroenterol (2015) 21(6):1804-13. doi:10.3748/wjg.v21.i6.1804

66. Zhang P, Chen Z, Ning K, Jin J, Han X. Inhibition of B7-H3 reverses oxaliplatin resistance in human colorectal cancer cells. Biochem Biophys Res Commun (2017) 490(3):1132-8. doi:10.1016/j.bbrc.2017.07.001

67. Sun ZZ, Zhang T, Ning K, Zhu R, Liu F, Tang SC, et al. B7-H3 upregulates BRCC3 expression, antagonizing DNA damage caused by 5-Fu. Oncol Rep (2016) 36(1):231-8. doi:10.3892/or.2016.4808

68. Jiang B, Liu F, Liu Z, Zhang T, Hua D. B7-H3 increases thymidylate synthase expression via the PI3k-Akt pathway. Tumour Biol (2016) 37(7):9465-72. doi:10.1007/s13277-015-4740-0

69. Vander Heiden MG, Cantley LC, Thompson CB. Understanding the Warburg effect: the metabolic requirements of cell proliferation. Science (2009) 324(5930):1029-33. doi:10.1126/science.1160809

70. Lim S, Liu H, Madeira da Silva L, Arora R, Liu Z, Phillips JB, et al. Immunoregulatory protein $\mathrm{B} 7-\mathrm{H} 3$ reprograms glucose metabolism in 
cancer cells by ROS-mediated stabilization of HIF1 $\alpha$. Cancer Res (2016) 76(8):2231-42. doi:10.1158/0008-5472.CAN-15-1538

71. Henrichsen CN, Chaignat E, Reymond A. Copy number variants, diseases and gene expression. Hum Mol Genet (2009) 18(R1):R1-8. doi:10.1093/hmg/ ddp011

72. Hnisz D, Shrinivas K, Young RA, Chakraborty AK, Sharp PA. A phase separation model for transcriptional control. Cell (2017) 169(1):13-23. doi:10.1016/j.cell.2017.02.007

73. Popovitchenko T, Rasin MR. Transcriptional and post-transcriptional mechanisms of the development of neocortical lamination. Front Neuroanat (2017) 11:102. doi:10.3389/fnana.2017.00102

74. Liang Z, Yang Y, He Y, Yang P, Wang X, He G, et al. SUMOylation of IQGAP1 promotes the development of colorectal cancer. Cancer Lett (2017) 411:90-9. doi:10.1016/j.canlet.2017.09.046

75. Dong P, Xiong Y, Watari H, Hanley SJ, Konno Y, Ihira K, et al. Suppression of iASPP-dependent aggressiveness in cervical cancer through reversal of methylation silencing of microRNA-124. Sci Rep (2016) 6:35480. doi:10.1038/ srep35480

76. Ihira K, Dong P, Xiong Y, Watari H, Konno Y, Hanley SJ, et al. EZH2 inhibition suppresses endometrial cancer progression via miR-361/Twist axis. Oncotarget (2017) 8(8):13509-20. doi:10.18632/oncotarget.14586

77. Dong P, Xiong Y, Hanley SJB, Yue J, Watari H. Musashi-2, a novel oncoprotein promoting cervical cancer cell growth and invasion, is negatively regulated by p53-induced miR-143 and miR-107 activation. J Exp Clin Cancer Res (2017) 36(1):150. doi:10.1186/s13046-017-0617-y

78. Huo W, Zhao G, Yin J, Ouyang X, Wang Y, Yang C, et al. Lentiviral CRISPR/ Cas9 vector mediated miR-21 gene editing inhibits the epithelial to mesenchymal transition in ovarian cancer cells. J Cancer (2017) 8(1):57-64. doi:10.7150/jca.16723

79. Dawson MA, Kouzarides T. Cancer epigenetics: from mechanism to therapy. Cell (2012) 150(1):12-27. doi:10.1016/j.cell.2012.06.013

80. Zhang P, Yu S, Li H, Liu C, Li J, Lin W, et al. ILT4 drives B7-H3 expression via $\mathrm{PI} 3 \mathrm{~K} / \mathrm{AKT} / \mathrm{mTOR}$ signalling and ILT4/B7-H3 co-expression correlates with poor prognosis in non-small cell lung cancer. FEBS Lett (2015) 589(17): 2248-56. doi:10.1016/j.febslet.2015.06.037

81. Nygren MK, Tekle C, Ingebrigtsen VA, Mäkelä R, Krohn M, Aure MR, et al. Identifying microRNAs regulating B7-H3 in breast cancer: the clinical impact of microRNA-29c. Br J Cancer (2014) 110(8):2072-80. doi:10.1038/ bjc. 2014.113
82. Wang L, Kang FB, Sun N, Wang J, Chen W, Li D, et al. The tumor suppressor miR-124 inhibits cell proliferation and invasion by targeting B7-H3 in osteosarcoma. Tumour Biol (2016) 37(11):14939-47. doi:10.1007/s13277016-5417-Z

83. Zhou X, Mao Y, Zhu J, Meng F, Chen Q, Tao L, et al. TGF- $\beta 1$ promotes colorectal cancer immune escape by elevating $\mathrm{B} 7-\mathrm{H} 3$ and $\mathrm{B} 7-\mathrm{H} 4$ via the miR-155/miR-143 axis. Oncotarget (2016) 7(41):67196-211. doi:10.18632/ oncotarget.11950

84. Liu K, Chen W, Lei S, Xiong L, Zhao H, Liang D, et al. Wild-type and mutant p53 differentially modulate miR-124/iASPP feedback following pohotodynamic therapy in human colon cancer cell line. Cell Death Dis (2017) 8(10):e3096. doi:10.1038/cddis.2017.477

85. Dong P, Ihira K, Hamada J, Watari H, Yamada T, Hosaka M, et al. Reactivating p53 functions by suppressing its novel inhibitor iASPP: a potential therapeutic opportunity in p53 wild-type tumors. Oncotarget (2015) 6(24):19968-75. doi:10.18632/oncotarget.4847

86. Wang ZS, Zhong M, Bian YH, Mu YF, Qin SL, Yu MH, et al. MicroRNA-187 inhibits tumor growth and invasion by directly targeting CD276 in colorectal cancer. Oncotarget (2016) 7(28):44266-76. doi:10.18632/oncotarget.10023

87. Zhao J, Lei T, Xu C, Li H, Ma W, Yang Y, et al. MicroRNA-187, down-regulated in clear cell renal cell carcinoma and associated with lower survival, inhibits cell growth and migration though targeting B7-H3. Biochem Biophys Res Commun (2013) 438(2):439-44. doi:10.1016/j.bbrc.2013.07.095

88. Potter M, Newport E, Morten KJ. The Warburg effect: 80 years on. Biochem Soc Trans (2016) 44(5):1499-505. doi:10.1042/BST20160094

89. Ma J, Ma P, Zhao C, Xue X, Han H, Liu C, et al. B7-H3 as a promising target for cytotoxicity $\mathrm{T}$ cell in human cancer therapy. Oncotarget (2016) 7(20):29480-91. doi:10.18632/oncotarget.8784

Conflict of Interest Statement: The authors declare that the research was conducted in the absence of any commercial or financial relationships that could be construed as a potential conflict of interest.

Copyright (®) 2018 Dong, Xiong, Yue, Hanley and Watari. This is an open-access article distributed under the terms of the Creative Commons Attribution License (CC BY). The use, distribution or reproduction in other forums is permitted, provided the original author(s) and the copyright owner(s) are credited and that the original publication in this journal is cited, in accordance with accepted academic practice. No use, distribution or reproduction is permitted which does not comply with these terms. 